Volume 7, No. 2, 2021

ISSN (print) : 2442-3217 / ISSN (online) : 2716-3806

Email : mimbarjurnal@gmail.com

Homepage : http://journal.iaimsinjai.ac.id/indeks.php/mimbar

DOI $\quad:$ https://doi.org/10.47435/mimbar.v7i2

\title{
KONSEP SEKSUAL DALAM ISLAM
}

\author{
Imam Zarkasyi Mubhar' ${ }^{1}$ Nurqalbyl Muthmainnah ${ }^{2}$, Nurfadillah Rusli ${ }^{3}$ \\ ${ }^{1}$ Institut Agama Islam Muhammadiyah Sinjai, Sulawesi Selatan \\ 1.imam086@gmail.com, ${ }^{2}$ mnurqalbyl@gmail.com, ${ }^{3}$ nurfadillahruslii@ gmail.com
}

\begin{abstract}
When we talk about sexuality, it is often misinterpreted as a conversation that is primarily about sex. Meanwhile, the extent of the discussion of sexuality is broader than just the issue of sex, which is more offensive to the organic angle. Sexuality is the way a person meets, appreciates, and communicates his thoughts as a sexual being. Overall, it concerns how a person uses his soul, making use of his feelings and actions depending on his situation as a sexual being. This paper discusses the idea of sexuality in Islam, the focus of the study is on sexuality in Islam. The formulation of this paper; First researching sexuality, there are people who react separately (actually) not as far as scholastic, also concentrating on sexuality will increase a person's capacity to be more subtle and careful in sexual relations with their partners. Issues in sexuality are about the notion of sexuality, the organization and the notion of sexuality in the Qur'an. The sex that is allowed and guaranteed by standards, religion and law is hetero provided that they must marry. For a while, there was another trend, namely a certain homosexuality. Gay people are not recognized in the public arena, especially tight networks. Islam has regulated things that are identical with sexuality, Islam gives space to heteros, on the grounds that it is sunnatullah. While homosexuality, both gay and lesbian, is a fahishah (terrible) act, such demonstrations are haram.
\end{abstract}

Keywords: Sexual and Islam

Abstrak

Pada saat kita berbicara tentang seksualitas, sering kali disalahartikan sebagai percakapan yang utamanya membahas tentang seks. Sedangkan luasnya perbincangan seksualitas lebih luas dari sekedar isu seks yang lebih menyinggung sudut organik. Seksualitas adalah cara seseorang bertemu, menghargai, dan mengomunikasikan pikirannya sebagai makhluk seksual. Secara keseluruhan, ini menyangkut bagaimana seseorang menggunakan jiwanya, memanfaatkan perasaan dan tindakannya tergantung pada situasinya sebagai makhluk seksual. Tulisan ini membahas tentang gagasan seksualitas dalam Islam, titik fokus kajiannya adalah tentang seksualitas dalam Islam. Rumusan makalah ini; Pertama meneliti seksualitas, ada orang yang bereaksi secara terpisah (sebenarnya) tidak sejauh skolastik, juga berkonsentrasi pada seksualitas akan meningkatkan kapasitas seseorang untuk lebih halus dan berhati-hati dalam hubungan seksual dengan pasangannya. Isu dalam seksualitas adalah tentang gagasan seksualitas, pengaturan dan gagasan seksualitas dalam Al-Qur'an. Jenis kelamin yang diperbolehkan dan dijamin oleh standar, agama dan hukum adalah hetero dengan catatan bahwa mereka harus menikah. Untuk sementara, ada kecenderungan lain, yaitu homoseksualitas tertentu. Orang gay tidak diakui di arena publik, terutama jaringan yang ketat. Islam telah mengatur hal-hal yang identik dengan seksualitas, Islam memberi ruang kepada heteros, dengan alasan bahwa itu adalah sunnatullah. Sedangkan homoseksualitas, baik gay maupun lesbian, adalah tindakan fahishah (mengerikan), maka demonstrasi seperti itu haram.

Kata Kunci: Seksual dan Islam 
Volume 7, No. 2, 2021

ISSN (print) : 2442-3217 / ISSN (online) : 2716-3806

Email : mimbarjurnal@gmail.com

Homepage : http://journal.iaimsinjai.ac.id/indeks.php/mimbar

DOI

: https://doi.org/10.47435/mimbar.v7i2

\section{Pendahuluan}

Alasan penulis membahas tentang seksualitas dalam Islam adalah pertama, menyajikan atau mengkaji seksualitas, sebagian bereaksi secara eksklusif (sebenarnya) tidak menurut perspektif ilmiah. Pandangan ini dengan alasan bahwa membahas atau berkonsentrasi pada seksualitas dipandang tidak konsisten dibandingkan dengan berkonsentrasi pada ilmu-ilmu yang berbeda seperti sains, ilmu fisika dan ilmu yang berbeda (Masters et al., 1992).

Ada poin penting yang harus dipahami bahwa berkonsentrasi pada seksualitas tidak berarti seseorang tidak memiliki nilai ilmiah, namun menunjukkan bahwa berkonsentrasi pada seksualitas memiliki praktik dan tidak sulit untuk dilakukan. Oleh karena itu, mengkaji seksualitas secara skolastik sebenarnya ingin membantu memberikan data yang tepat tentang seksualitas sehingga dapat mencegah masalah seksualitas yang akan terjadi dan bekerja secara fisik sesuai kapasitasnya.

Terlebih lagi, berbicara tentang seksualitas atau dalam hal apapun, memberikan pendidikan seksualitas kepada usia yang lebih muda lebih baik. Memberikan informasi yang baik tentang seks dan seksualitas dapat membantu daerah setempat dalam menangani kasus-kasus seksual yang mereka hadapi dalam kehidupan mereka, termasuk kasus kemandulan, kerusakan seksual, penyakit seksual, kebiadaban seksual, penyimpangan seksual dan lain-lain. Kedua, pendapat berikut adalah bahwa berkonsentrasi pada seksualitas akan menarik kemampuan individu untuk lebih sensitif dan waspada dalam berhubungan seks dengan pasangannya.

Dari hasil beberapa peneliti yang ada didalam jurnal khususnya pada jurnal salah satu dosen di IAIM SINJAI mengatakan bahwa seks adalah kebutuhan setiap insan, akan tetapi seks dalam fitrahnya diarahkan pada sisi positif sehingga dapat mewujudkan perkembangan yang searah dengan konsepsi yang islamic karena bentuk penyimpangan seks seseorang baik dalam bentuk homoseksual atau lesbian atau lebih dikenal dengan istilah LGBT dapat berakibat 


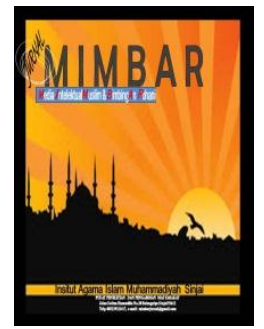

Volume 7, No. 2, 2021

ISSN (print) : 2442-3217 / ISSN (online) : 2716-3806

Email : mimbarjurnal@gmail.com

Homepage : http://journal.iaimsinjai.ac.id/indeks.php/mimbar

DOI

: https://doi.org/10.47435/mimbar.v7i2

pada kelainan dalam proses perkembangan kepribadian seseorang. Selain itu, perilaku ini sudah menyimpang dari ajaran agama (Kusnadi, 2020).

Berbicara tentang seksualitas memang mengerikan, sama halnya mengingat fakta bahwa setiap individu memiliki kecenderungan atau arah seksual yang berbeda. Disadari bahwa dalam hubungan seksual penyebaran hubungan seksual adalah dengan sesama jenis (hetero), dan ada juga jenis homoseksualitas di mana penyampaian hubungan seksual adalah sesama jenis, terlepas dari apakah gay, lesbian atau tidak bias secara seksual. Hal ini diungkapkan dalam al-Qur'an melalui terma-terma yang semakna yakni, jima'/Ikhtilat, syahawat, alita', almubasharah, al-qurbu, al-ifdla, istimta', dhukhul bi, al-mulamasah, al-zakar, aluntha', alRajul/al-Rijal dan al-Nisa/al-Mar'ah, yang berasal dari kata bercampur, menggauli, hubungan badan, pandangan, jenis kelamin (seks),gender.. Yang mempunyai arti serupa yakni: menggauli, bercampur dan hubungan badan.

Dalam jurnal ini metode yang digunakan adalah metode deskriptif yaitu menyajikan deskripsi sebagaimana adanya dan analisa lebih mendalam, karena objek kajiannya hanya pada ayat-ayat maka pendekatan yang tepat adalah tafsir maudhu'i. Untuk mendapatkan kajian mendalam tentang konsep seksual dalam islam dengan tujuan memahami hakikat seksual dalam islam, klasifikasi dan konsep seksual dalam al-qur'an. Hal ini disebabkan oleh persoalan-persoalan pemahaman tentang konsep seksual dalam islam yang masih kurang di dalami oleh masayarakat muslim. Oleh karena itu, penulis berusaha semaksimal mungkin untuk mengungkapkan konsep tersebut melalui kajian ayat-ayat al-Qur'an.

\section{Metode}

\section{Hasil dan Pembahasan}

\subsection{Hakikat Seksual Dalam Islam}

\subsubsection{Defenisi Seksual}

Arti dari kata jima' secara bahasa diambil dari kata Jama yujami'u mujami'atan wajimaan yang artinya "berkumpul atau bersetubuh, misalnya kalimat jima'ul mar'ati yang artinya berhubungan badan dengan seorang wanita (Muhdlor \& Ali, 1996). Pada kalimat tersebut kata jima 'murodif tidak dapat 
Volume 7, No. 2, 2021

ISSN (print) : 2442-3217 / ISSN (online) : 2716-3806

Email : mimbarjurnal@gmail.com

Homepage : http://journal.iaimsinjai.ac.id/indeks.php/mimbar

DOI $\quad:$ https://doi.org/10.47435/mimbar.v7i2

dipisahkan dari kata wathi'. Whati'ul Mar'ati Bijimaiha Jadi kata jima' berarti persetubuhan antara laki-laki dan perempuan. Kedua kata ini lebih menekankan pada perkembangan seksual. Jima' yang berarti seks, sesekali juga memiliki arti penting yang mendalam, di mana setiap hubungan seksual dan terlebih lagi kondisi yang menyerupai hubungan seksual (misalnya, keduanya dalam posisi seksual belum masuk atau hasyafah dan klitoris belum iltiqo) bagi sebagian orang, individu dikatakan memiliki "hubungan". Kata lain yang memiliki arti penting persetubuhan adalah lafadh Iltiqo'ul Khithanaini. Lafadz Ilthiqo' berkonotasi: pertemuan. Lafadz hitana adalah sejenis tatsniyah, hitani isim masdar dari kata hitanu. Arti penting kata sunat dalam bahasa Arab adalah pemotongan alat kelamin laki-laki atau perempuan (Asrari, 1998), (sunat = jawa). Bagian ini adalah al-hasyafah (penis) pada alat kelamin laki-laki dan al-qodhib (kelentit) pada alat kelamin/vagina wanita.

Menurut DR. Abdullah Nashih Ulwan dalam bukunya Tarbiyah al-Aulâd Fi al-Islam, khitan juga menyiratkan bagian yang dipotong atau di mana hasil hukum Syariah muncul (Asrari, 1998). Pentingnya lafadz ini lebih jauh menjelaskan makna jima', mengingat lafadh iltiqo'ulkhitana ini menekankan pentingnya kata pada pertemuan tata cara berhubungan seks yang mengandung unsur syarat terhukum "pesta".

Melihat pentingnya lafadz ini, akan terlihat bahwa dua kemaluan yang disunat (hasyafah dan klitoris) dapat bertemu jika sebelumnya lewat melalui khasyafah ke dalam vagina. karena klitoris yang menonjol terletak di bagian atas vagina, di atas tempat keluarnya air seni. karena klitoris yang menonjol terletak di bagian atas vagina, di atas tempat keluarnya air seni. Misalnya dengan lafadz iltiqo'ulkhitanain yang memiliki arti penting persetubuhan dan menggarisbawahi arti penting kata tentang tata cara bersetubuh adalah lafadz taghayyibal hasyafati yang artinya: "mengeluarkan atau mencekik/memasukkan hasyafah ke dalam vagina". Lafadz taghayyibal hasyafati dan iltiqo'ulkhitanaini yang penonjolan pentingnya lafadz adalah "alat persetubuhan" membuat keduanya semakin "tak tergoyahkan dalam arti penting persetubuhan". Keteguhan akan pentingnya lafadz ini sangat mendorong berkembangnya hasil yang halal. Mungkin inilah yang 
Volume 7, No. 2, 2021

ISSN (print) : 2442-3217 / ISSN (online) : 2716-3806

Email : mimbarjurnal@gmail.com

Homepage : http://journal.iaimsinjai.ac.id/indeks.php/mimbar

DOI $\quad:$ https://doi.org/10.47435/mimbar.v7i2

mendorong Imam al-Sayuthi untuk memilih kata taghayyibal hasyafati untuk menjelaskan akibat sahnya jimae dalam kitabnya al-Asybâh wa al-Nadhâir fi Qowâ'id wa Furü' Fiqh al-Syafi'i. Keempat lafadz (wathi', jima', iltiqo'ulkhitanaini, taghayyibal hasyafati) ini sangat terkenal dan sering ditemukan dalam kitab-kitab fiqh. Masing-masing dari empat memiliki kepentingan dan alasan yang sama, namun memiliki pilihan lain "aksentuasi signifikansi". Perbedaan dalam pelengkap kepentingan ini membuat kesempatan "berlawanan dengan melemahnya kepentingan". Lafadz taghayyibal dan iltiqo'ulkhitana lebih menekankan pentingnya konsentrasi dalam bersenggama, dengan alasan keduanya memiliki arti penting "pintu masuk" yang merupakan kunci utama dalam bersenggama dibandingkan dengan lafadz jima' dan watha' sehingga seks menyimpulkan seksual (Kbbi, 2016). yakni laki-laki dan perempuan. khusus orang. Sedangkan dalam penyusunannya adalah keinginan, yang merupakan pendorong utama kehidupan, yang menggunakan beberapa nama antara lain intuisi, dorongan yang digerakkan oleh orang, indera yang digerakkan oleh orangorang yang menyatukan mereka, untuk dilanjutkan dengan kelanjutan terjun manusia (Akbar, 1986).

Seksualitas adalah tentang bagaimana seorang individu bertemu, hidup dan mengartikulasikan pikirannya sebagai makhluk seksual, seperti yang berkaitan dengan bagaimana seorang individu berpikir, merasa dan bertindak tergantung pada situasinya sebagai makhluk seksual. Semua yang berhubungan dengan seks (ada hubungannya dengan seks) diingat untuk itu. Seks hanyalah satu sudut pandang, namun seksualitas secara keseluruhan selalu terhubung dengan seks (hubungan) (Hannah, 2017).

Pendapat lain mengatakan bahwa kata seks dapat berarti proses proliferasi atau kontras dalam kepribadian jenis kelamin, dan juga dapat menjadi hampir semua hal yang berhubungan dengan kesenangan atau pemenuhan organ yang digabungkan dengan dorongan organ genital atau dikaitkan dengan belaian dan persetubuhan (Marzuki, 2001).

Pada dasarnya hukum jima' (bersetubuh) dengan pasangan diperbolehkan dan ini adalah hukum dasar jima', karena dalam hal pernikahan, apa yang selama 


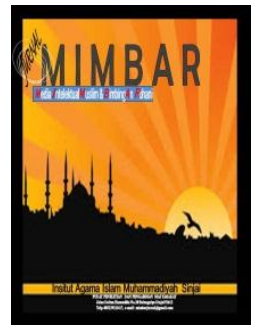

MIMBAR

Jurnall Media Intelektual Muslim dan Bimbingan Rohani

Volume 7, No. 2, 2021

ISSN (print) : 2442-3217 / ISSN (online) : 2716-3806

Email : mimbarjurnal@gmail.com

Homepage : http://journal.iaimsinjai.ac.id/indeks.php/mimbar

DOI $\quad:$ https://doi.org/10.47435/mimbar.v7i2

ini tabu untuk dilakukan menjadi sah dan diperbolehkan bagi pasangan yang menikah. melakukan itu adalah jima' (berhubungan badan).

\subsubsection{Jima' Menurut Fuqoha'}

Penggunaan bahasa jima' dalam fikih, di mana fikih sebagai disiplin ilmu hukum Islam, jelas juga memiliki arti penting yang halal, yang artinya; Jima' macam apa yang bisa mendorong lahirnya hukum Syara'? Hasil paling ringan halal dari persetubuhan adalah komitmen untuk berwudhu (Tholabah, 2002), sedangkan konsekwensi yang lainnya lebih berat, seperti had, wajibnya mahar dan lain-lain (Al-Manawiy, 1972). Setiap ilmuwan madzhab (Syafi'i, Maliki, Hanafi, Hambali dan Ja'fari) sepakat bahwa persetubuhan (jima') dengan bagian atas dhakar atau bagian hasyafah ke dalam farji telah mewajibkannya. untuk mandi, padahal maninya belum keluar. Ijma 'almadzahib menunjukkan bahwa jima' yang dapat berdampak otentik adalah adanya taghayyibal hasyafati)/serbuan atau iltiqo'ulkhitanaini/berkumpulnya hasyafah dan klitoris dalam hubungan intim yang nyaman. Kondisi ini adalah metode untuk memilih apakah suatu jima ${ }^{e e}$ telah terjadi atau tidak. Imam Syafi'i tidak mengenal manusia dan hewan, yang semuanya harus dicuci. Kualifikasi ini memberikan pengaturan bahwa farji adalah modus untuk segmen hasyafah. Dalam Ianah al-Thalibin Juz I terungkap bahwa luasnya makna lafadh al-farj sebagai aurat wanita karena lafadz al-farj diambil dari kata infaroja yang mengandung makna infataha, yang berarti terbuka, jauh dan luas/fleksibel. ", farji bergabung dengan qubul/vagina dan dubur/punggung. Qubul dan bagian belakang juga memiliki arti yang luas, termasuk makhluk hidup atau mati, jin, dan hewan hidup meskipun tidak menimbulkan dorongan, misalnya farji ikan. Wadah Muhammad Nawawi Umar al-Jawiy, seorang ilmuwan Mekkah dari Banten, dalam bukunya Tausyih Alâ Ibn Qâsim menambahkan bahwa; Menerima seseorang dapat menanamkan hasyafahnya ke pantatnya sendiri, dia juga telah dicaci karena jima' sehingga dia harus membersihkannya (Al-Jawiy, 1996).

\subsubsection{Teori Hukum Islam Tentang Hubungan Seksual}

Perspektif Islam tentang seksualitas bergantung pada informasi tentang naluri manusia dan kepuasan seksualnya sehingga setiap orang di arena publik 


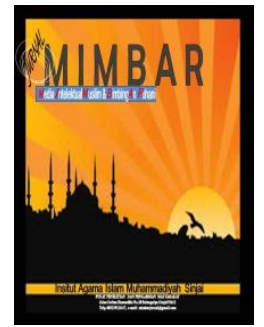

MIMBAR

Jurnal Media Intelektual Muslim dan Bimbingan Rohani

Volume 7, No. 2, 2021

ISSN (print) : 2442-3217 / ISSN (online) : 2716-3806

Email : mimbarjurnal@gmail.com

Homepage : http://journal.iaimsinjai.ac.id/indeks.php/mimbar

DOI

: https://doi.org/10.47435/mimbar.v7i2

tidak melampaui batasan kecenderungannya. Dia harus berjalan dengan cara yang khas seperti yang telah ditetapkan oleh Islam. Firman Allah Qs. Ar-Rum/30:21 :

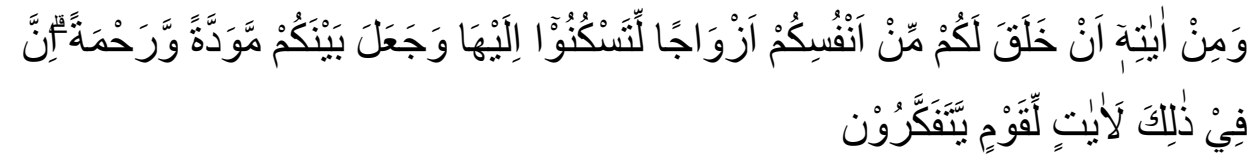

Artinya: dan di antara tanda-tanda kekuasaan-Nya ialah Dia menciptakan untukmu isteri-isteri dari jenismu sendiri, supaya kamu cenderung dan merasa tenteram kepadanya, dan dijadikan-Nya diantaramu rasa kasih dan sayang. Sesungguhnya pada yang demikian itu benar-benar terdapat tanda-tanda bagi kaum yang berfikir. (Qs. Ar-ruum/30:21) (Al-Karim, 2008)

Dalam ajaran Islam, seks adalah bagian yang penting, seperti halnya persyaratan untuk berhubungan seks dengan keberadaan manusia. Lebih dari itu, pelajaran menempatkan seks sebagai cinta, jika dilakukan sesuai hukum Islam dan diatur dalam pernikahan yang diberkati. Oleh karena itu perkawinan sangat ditekankan dalam ajaran Islam, karena seks di luar nikah tidak dapat diatur dalam Islam, karena dapat merugikan orang lain.

Islam tidak menyerukan apa-apa dan hubungan seksual yang khas melalui pernikahan dengan niat penuh untuk mendedikasikan semua kesempatannya untuk menyembah Allah. Islam adalah syariat yang tidak berpikir dua kali tentang kemurkaan kehidupan dunia lain dan kehidupan pantangan yang tidak dapat dipertahankan dengan alasan bertentangan dengan naluri manusia dan menolak kecenderungan indera manusia. Nabi SAW bersabda yang artinya: Barang siapa yang bisa menikah, maka pada saat itu tidak menikah, maka pada saat itu, dia bukanlah salah satu dari umatku. (Dijelaskan oleh Bukhori)

Untuk menaklukkan kerusakan ruh dan mengarahkannya untuk menjadi pribadi yang terhormat, Islam membutuhkan naluri manusia untuk dijalankan oleh keinginan Yang Mahakuasa.

\subsubsection{Ayat-Ayat Tentang Seks}

Sebagaimana yang telah diuraikan sebelumnya bahwa fokus kajian seksual dalam tulisan ini mengarah pada terma jima'/Ikhtilat, syahawat, alita', almubasharah, al-qurbu, al-ifdla, istimta', dhukhul bi, al-mulamasah, al-zakar, aluntha', alRajul/al-Rijal dan al-Nisa/al-Mar'ah, yang berasal dari kata bercampur, 


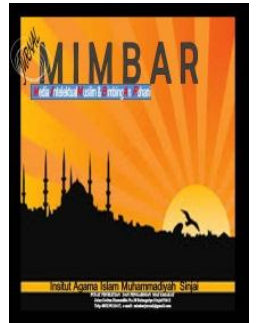

Volume 7, No. 2, 2021

ISSN (print) : 2442-3217 / ISSN (online) : 2716-3806

Email : mimbarjurnal@gmail.com

Homepage : http://journal.iaimsinjai.ac.id/indeks.php/mimbar

DOI : https://doi.org/10.47435/mimbar.v7i2

menggauli, hubungan badan, pandangan, jenis kelamin (seks),gender. Maka, untuk mengetahui makna yang terkandung di dalamnya, terlebih dahulu perlu dilacak kata melalui asal kalimatnya menggunakan kitab Mu'jam Mufahras Li AlFadzi Al-Qur'an untuk mengetahui ayat-ayat yang menggunakan term tersebut dalam al-Qur'an.

a. Kata jima'/Ikhtilat, alita', al-mubasharah, al-qurbu, al-ifdla, istimta', dhukhul bi, al- mulamasah, dengan seluruh bentuk devariasinya di dalam alQur'an yang terulang sebanyak 16 kali sebagaimana berikut:(Al-Baqiy, 1364)

b. Kata al-zakar, al-untha' dengan seluruh bentuk devariasinya di dalam alQur'an yang terulang sebanyak 10 kali sebagaimana berikut:(Al-Asfahāni, n.d.)

c. Kata al Rajul/al-Rijal dan al-Nisa/al-Mar'ah dengan seluruh bentuk devariasinya di dalam al-Qur'an yang terulang sebanyak 101 kali sebagaimana berikut:

Demikian ayat-ayat diatas yang ditunjukkan dalam kitab Mu'jam Mufahras Li Al-Fadzi Al-Qur'an dari kata jima'/Ikhtilat, syahawat, alita', almubasharah, al-qurbu, al-ifdla, istimta', dhukhul bi, al-mulamasah, al-zakar, aluntha', al Rajul/al-Rijal dan al-Nisa/al-Mar'ah, yang berasal dari kata bercampur, menggauli, hubungan badan, pandangan, jenis kelamin (seks),gender dalam Al-Qur'an.

\subsection{Klasifikasi Ayat Seksual Dalam Al-Qur'an}

Dalam mengkaji seksualitas dalam sudut pandang Islam, jelas mengacu pada Al-Qur'an. Sebagai sumber hukum bagi umat Islam, dalam Al-Qur'an ada beberapa pantangan yang menjelaskan tentang seksualitas adalah sebagai berikut;

3.1.1 Ayat yang menerangkan hubungan heteroseksual Hubungan heteroseksual (suami istri) merupakan sunnatullah.

1) QS. Ar-Rum [30]:21.

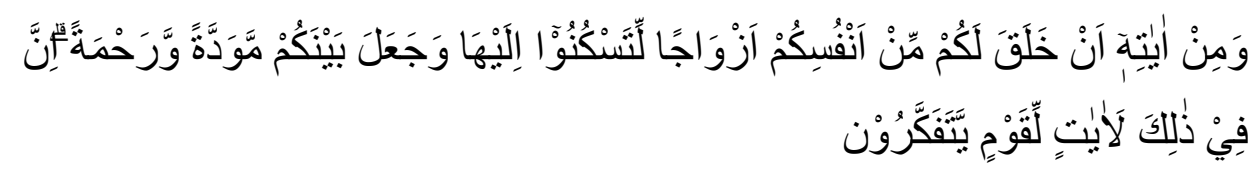


Volume 7, No. 2, 2021

ISSN (print) : 2442-3217 / ISSN (online) : 2716-3806

Email : mimbarjurnal@gmail.com

Homepage : http://journal.iaimsinjai.ac.id/indeks.php/mimbar

DOI : $\quad$ https://doi.org/10.47435/mimbar.v7i2

"Dan di antara tanda-tanda kekuasaan-Nya ialah Dia menciptakan untukmu isteri-isteri dari jenismu sendiri, supaya kamu cenderung dan merasa tenteram kepadanya, dan dijadikan-Nya diantaramu rasa kasih dan sayang. Sesungguhnya pada yang demikian itu benar-benar terdapat tanda-tanda bagi kaum yang berfikir." (QS. al-Rum [30]: 21)

Dalam tafsir Jalalayn (Dan di antara indikasi kekuatan-Nya adalah bahwa Dia membuat untuk Anda pasangan dari jenis Anda sendiri) Siti Hawa dibuat dari tulang rusuk Nabi Adam sementara orang yang berbeda dibuat dari air mani orang (sehingga Anda cenderung dan merasa tenang dengan dia) sehingga Anda merasa nyaman dengan dia (dan membuatnya di antara semua) semua (cinta. Tidak diragukan lagi, dalam hal) hal-hal yang telah dirujuk (pasti ada menyelesaikan dokumen untuk orang yang berpikir ) khususnya yang orang yang merenungkan ciptaan Allah swt.

Pada bagian ini dijelaskan indikasi kekuasaan Allah, khususnya kehidupan bersama antara seorang pria dan seorang wanita dalam sebuah pernikahan. Orangorang menyadari bahwa mereka memiliki kasih sayang khusus untuk jenis lain. Sentimen dan perenungan ini ditimbulkan oleh daya tarik yang ada pada masingmasingnya, yang membuat yang satu tertarik ke yang berikutnya, sehingga antara dua jenis, laki-laki dan perempuan, ada hubungan yang khas. Mereka berani maju dan berusaha untuk mencapai sentimen dan kecenderungan di antara orang-orang (Tafsir, n.d.).

Puncak dari ini adalah pernikahan antara seorang pria dan seorang wanita. Dalam keadaan seperti itu, bagi seorang pria hanya separuh yang lebih baik darinya adalah wanita terbaik, sedangkan bagi seorang wanita hanya pasangannya yang menarik hatinya. Masing-masing merasa terhibur dengan kehadiran pasangan tersebut. Ini adalah modal paling signifikan dalam membina keluarga yang ceria. Dengan keluarga yang bahagia, jiwa dan otak menjadi tenteram, tubuh dan hati menjadi tenang, kehidupan dan pekerjaan menjadi konsisten, semangat hidup akan muncul, dan keharmonisan bagi orang-orang akan tercapai secara keseluruhan.

2) QS. al-Nisa' ayat 1; 


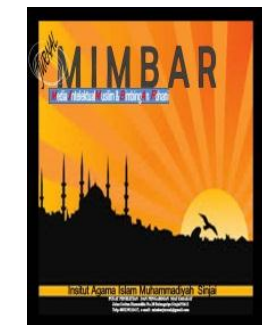

Volume 7, No. 2, 2021

ISSN (print) : 2442-3217 / ISSN (online) : 2716-3806

Email : mimbarjurnal@gmail.com

Homepage : http://journal.iaimsinjai.ac.id/indeks.php/mimbar

DOI $\quad:$ https://doi.org/10.47435/mimbar.v7i2

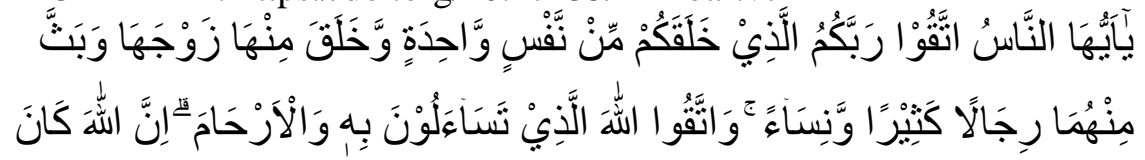

عَلَيْكُْْ رَفَبْيًَا

"Hai sekalian manusia, bertakwalah kepada Tuhan kamu yang telah menciptakan kamu dari diri yang satu, dan dari padanya Allah menciptakan istrinya; dan dari pada keduanya Allah mengembangkan keturunan lelaki dan wanita yang banyak. Dan bertakwalah kepada Allah yang dengan (mempergunakan) namaNya kamu saling meminta satu sama lain, dan (peliharalah) hubungan silaturrahim. Sesungguhnya Allah selalu menjaga dan mengawasi kamu." [QS. AnNisa' [4]: 1).(Al-Karim, 2008)

Dari tafsir Jalalayn menjelaskan (hai manusia) penduduk Mekkah (takut terhadap Penguasamu) menyiratkan ketakutan akan disiplin-Nya dengan mematuhi-Nya (yang menjadikanmu dari satu diri) menjadi Adam tertentu (dan menjadikan darinya pasangannya yang penting) secara khusus. Hawa, dari salah satu tulang rusuk kirinya (dan sesudahnya bertambah) menyebar (dari keduanya) Adam dan Hawa (banyak orang) yang tidak sedikit jumlahnya. (Selanjutnya takut kepada Allah bahwa Anda saling bertanya) ada idgam ta pada kezaliman, sementara pada saat yang sama ditunjukkan oleh satu qiraat dengan takhfif, yaitu membuangnya sehingga berubah menjadi bungkus aluuna (dengan nama-Nya) yang sebagian dari kamu berkata kepada orang lain, "Aku memohon kepadamu dengan menyebut nama Allah," (Dan selanjutnya) berhati-hatilah (sambungan) jangan putus. Seperti yang ditunjukkan oleh satu qiraat, itu dibaca dengan kasrah yang dicatat pada dhamir yang terkandung dalam bihi. Mereka juga biasa bersumpah satu sama lain dengan hubungan rahim. (Sesungguhnya Allah terusmenerus menjaga Anda) memantau perbuatan Anda dan menghargai mereka. Jadi ide mengawasi selalu ditambahkan dan ditemukan dalam Allah swt. Bagian berikutnya dibuka sehubungan dengan penjaga gerbang gelandangan untuk kelimpahannya tetapi dia tidak ingin memberikannya.(Tafsir, n.d.)

3.1.2 Ayat yang menerangkan tentang hubungan kehalalan seksual (pernikahan),

1) Qs. Al-A’raf/7:189 


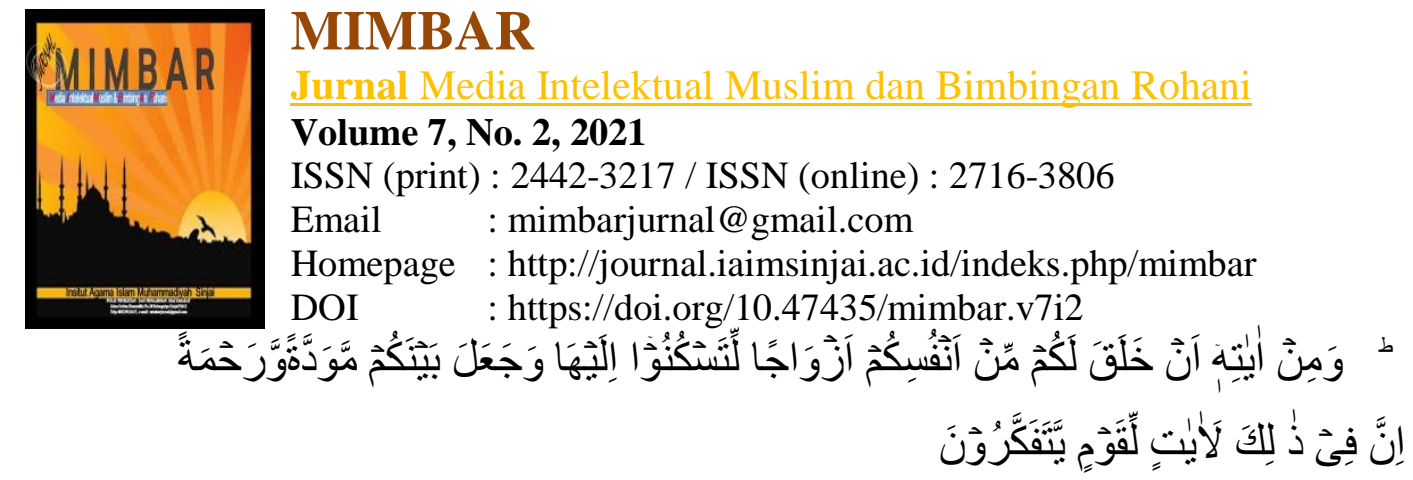

"Dan di antara tanda-tanda (kebesaran)-Nya ialah Dia menciptakan pasangan-pasangan untukmu dari jenismu sendiri, agar kamu cenderung dan merasa tenteram kepadanya, dan Dia menjadikan di antaramu rasa kasih dan sayang. Sungguh, pada yang demikian itu benar-benar terdapat tanda-tanda (kebesaran Allah) bagi kaum yang berpikir. "(Al-Karim, 2008)

Tafsir: Itulah cara Allah mengalihkan pandangan mereka untuk fokus pada keadaan Dakwah dan lebih jauh lagi untuk fokus pada alam semesta sehingga mereka bisa merasakan keesaan Tuhan. Kali ini Allah menyambut mereka untuk membaca dengan teliti realitas saat ini di dalam diri mereka, untuk lebih spesifik bahwa Dia, Allah, yang menjadikan Anda kerabat Nabi Adam dari jiwa yang menyendiri, khususnya Nabi Adam, dan darinya Dia menjadikan kaki tangannya, khususnya Hawa, jadi dia akan merasa tenang dan memiringkan hatinya ke kaki tangannya. Jadi setelah dia membaur, bagian perutnya yang lebih baik memiliki perut yang ringan, seperti yang biasa terjadi pada awal kehamilan, dan dia terus merasa ringan selama beberapa waktu. Kemudian, pada saat itu, ketika dia merasa berat, ketika perutnya semakin besar dan kesempatan yang ideal untuk transportasi semakin dekat, mereka berdua, khususnya pasangan, bertanya kepada Allah, Tuan mereka, dengan mengatakan, "Demi kekuatan dan kebesaran-Mu., jika Engkau memberi kami anak yang saleh, hebat, kuat, dan tidak cacat, tentu kami adalah pribadi yang sangat menghargai."(Tafsir, n.d.)

Dalam ayat ini, Allah menjelaskan bahwa manusia diciptakan dari satu jenis, dan dari jenis itu dijadikan kaki tangannya, jadi mereka hidup berdua, pria dan wanita (pasangan) dan dia menemukan rasa puas dengan pasangannya. Hidup berpasangan adalah karakteristik dan kebutuhan manusia dunia lain. Pada saat seseorang telah mencapai usia dewasa, muncul keinginan untuk hidup berdua-dua sebagai pasangan, dan ia akan mengalami gangguan jiwa jika keinginan tersebut tidak terpenuhi. Karena dalam berpasangan itulah yang diakui kerukunan. Ketenangan tidak akan diakui pada orang-orang di luar hidup dua per dua pasangan. Jadi motivasi di balik kehadiran pasangan bagi seorang pria dalam 


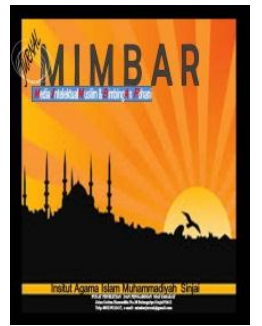

Volume 7, No. 2, 2021

ISSN (print) : 2442-3217 / ISSN (online) : 2716-3806

Email : mimbarjurnal@gmail.com

Homepage : http://journal.iaimsinjai.ac.id/indeks.php/mimbar

DOI $\quad:$ https://doi.org/10.47435/mimbar.v7i2

Islam adalah untuk membuat hidup dua dengan dua itu sendiri. Islam mengharapkan orang untuk hidup berpasangan, dengan alasan bahwa dalam keadaan hidup seperti itu orang menemukan harmoni dan kepuasan yang mendalam dan aktual.

2) Qs. An-Nahl/16:72

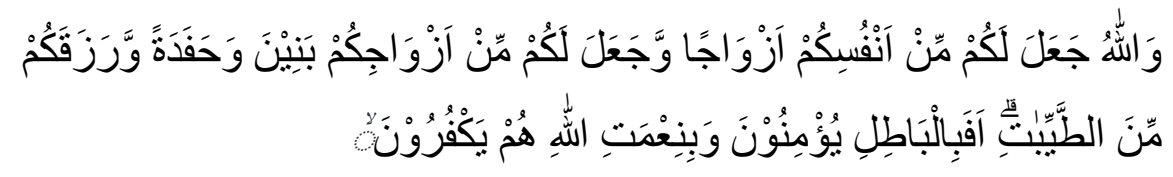

"Dan Allah menjadikan bagimu pasangan (suami atau istri) dari jenis kamu sendiri dan menjadikan anak dan сиси bagimu dari pasanganmu, serta memberimu rezeki dari yang baik. Mengapa mereka beriman kepada yang batil dan mengingkari nikmat Allah? '(Al-Karim, 2008)

Tafsir: Kemudian, pada saat itu, Allah menjelaskan persetujuan-Nya, khususnya bahwa Allah swt telah membuat kaki tangan bagi mereka dari jenis mereka sendiri. Pasangan adalah kaki tangan dalam bekerja sama untuk mengumpulkan keluarga dan jaringan. Dengan pasangan itu, manusia dapat memiliki keturunan untuk mengikuti dan membina umat manusia dalam menyelesaikan kewajibannya sebagai khalifah di muka bumi ini. Kemudian, pada saat itu, Allah menjelaskan bahwa Dialah yang telah memberi mereka makanan dan minuman yang banyak dan bermanfaat. Oleh karena itu, masyarakat tidak perlu takut akan tantangan dalam memperoleh makanan karena anak-anak. Semua hal yang sama, mereka harus mendidik anak-anak sehingga mereka akan benarbenar ingin melakukan kewajiban mereka sebagai khalifah di bumi ketika mereka tumbuh dewasa (Tafsir, n.d.).

\subsection{Konsep Seksual Dalam Al-Qur'an}

\subsubsection{Ruang lingkup seksual dalam al-Qur'an}

Membahas seksualitas dalam Al-Qur'an harus dilakukan dengan hati-hati mengingat masalah ini adalah masalah yang sangat esensial. Al-Qur'an memang tidak secara eksplisit menjelaskan tentang seksualitas. Namun juga jangan menghindari pembahasan ini. Membahas seksualitas dalam Al-Qur'an lebih condong pada hubungan seksual sebagai pasangan dibandingkan seks sebagai kebebasan umum individu. Selanjutnya, pembicaraan tentang perkawinan sebagai 


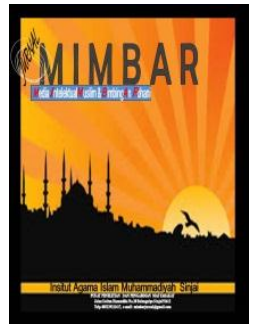

Volume 7, No. 2, 2021

ISSN (print) : 2442-3217 / ISSN (online) : 2716-3806

Email : mimbarjurnal@gmail.com

Homepage : http://journal.iaimsinjai.ac.id/indeks.php/mimbar

DOI

: https://doi.org/10.47435/mimbar.v7i2

pengaturan hubungan sosial-seksual mendapat penjelasan yang benar-benar lengkap dibandingkan dengan seksualitas sebagai hak setiap orang. Isu seksualitas yang disarankan oleh Al-Qur'an mencakup hal-hal seperti pernikahan, perpisahan, perlakuan terhadap pasangan dalam kehidupan rumah tangga (muasyarah bil ma'ruf), iddah dan isu-isu yang diidentifikasi dengan penyimpangan seksual, misalnya, kisah individu Luth yang homoseksualitas yang dilatih.

Hal ini menunjukkan bahwa sebagai kitab yang diberkahi, Al-Qur'an adalah kitab yang bereaksi terhadap persoalan-persoalan kemanusiaan. Pada dasarnya ada dua misi mengapa Alquran membahas seksualitas. Pertama, diskusi ini dimaksudkan untuk melawan sejarah seksualitas sebelumnya. Masa lalu yang dimaksud adalah masa sebelum munculnya Islam yang tentunya sering kita sebut dengan masa jahiliyah. Pada masa pra-Islam ini, tampaknya Al-Qur'an memiliki pandangan yang menghina (memberi makna yang menyinggung).

Prof. Dr. Hazairin, S.H. dalam bukunya Public Family Law mengatakan intisari dari pernikahan adalah hubungan seksual. Menurut dia, tidak ada (perkawinan) jika tidak ada hubungan seksual. Dia mengambil gambar bahwa dengan asumsi tidak ada hubungan seksual di antara pasangan, tidak ada persyaratan untuk waktu tunggu (iddah) untuk menikahi mantan dengan pria lain (Hazairin, 1961).

Hal penting dalam gagasan Al-Qur'an tentang seks/seksualitas adalah bahwa Al-Qur'an tidak membuat jaminan yang meremehkan wanita dan seks, bahkan terhadap praktik misantropis. Hal ini terlihat dalam Alquran yaitu:

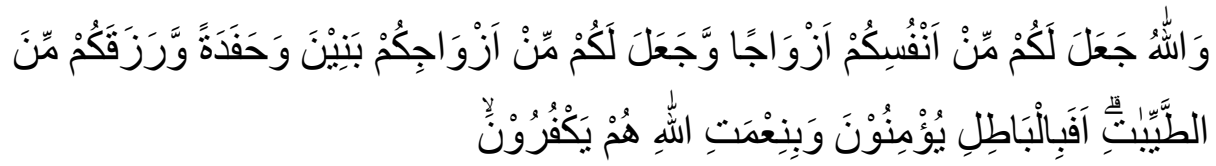

"Dan Allah menjadikan bagimu pasangan (suami atau istri) dari jenis kamu sendiri dan menjadikan anak dan сиси bagimu dari pasanganmu, serta memberimu rezeki dari yang baik. Mengapa mereka beriman kepada yang batil dan mengingkari nikmat Allah?"(qs. An-Nahl:27)(Al-Karim, 2008)

Pada tafsir Jalalain (Kemudian, pada saat itu, Allah mempermalukan mereka Setelah kedatangan Pemulihan) membuat mereka mempermalukan (dan berkata) Allah kepada mereka melalui lidah utusan surgawi-Nya dengan nada 
Volume 7, No. 2, 2021

ISSN (print) : 2442-3217 / ISSN (online) : 2716-3806

Email : mimbarjurnal@gmail.com

Homepage : http://journal.iaimsinjai.ac.id/indeks.php/mimbar

DOI $\quad$ : https://doi.org/10.47435/mimbar.v7i2

mengejek ("Di mana kaki tangan-Ku?) karena menjaganya Anda secara konsisten mengancam) terhadap para penyembah (tentang mereka.") sehubungan dengan kasus mereka. (Katakanlah) menyiratkan bahwa nanti mereka akan mengatakan/membalas (orang-orang yang diberi informasi) khususnya para nabi dan para pengikutnya ("Yang pasti, rasa malu dan disiplin saat ini akan menimpa orang-orang yang tidak percaya.") Para nabi dan umat katakanlah sebagai lelucon kepada orang-orang kafir. Terjemahan Jalalayn (Kemudian, pada saat itu, Allah mempermalukan mereka Setelah kedatangan Pemulihan) membuat mereka mempermalukan (dan berkata) Allah kepada mereka melalui lidah utusan surgawi-Nya dengan nada mengejek ( "Di mana kaki tangan-Ku?) karena melindunginya, Anda terus-menerus mengancam) terhadap para penyembah (tentang mereka.") sehubungan dengan kasus mereka. (Katakanlah) menyiratkan bahwa nanti mereka akan mengatakan/membalas (orang-orang yang diberi informasi) secara spesifik para nabi dan para pengikutnya ("Tanpa diragukan lagi, rasa malu dan disiplin saat ini akan menimpa orang-orang yang bertanya.") Para nabi dan umat mengatakan sebanyak lelucon untuk skeptis. Dalam ayat ini, bisa dilihat tanda kekuasaan sang Pencipta ketika Allah menjadikan kita semua berpasang-pasangan, suami dan istri agar menggapai ketenangan hidup. Selain itu, menjadikan anak dan cucu, memberikan rezeki dan anugerah yang baik sesuai kebutuhan hidup manusia.

\subsubsection{Bentuk-Bentuk Motif Seks dalam al-Qur'an}

Proses berpikir tentang seks yang ada pada orang umumnya baik. Dengan demikian, apabila tidak mendapatkan sosialisasi yang baik, maka akan menimbulkan ketidakteraturan dalam perilaku manusia itu sendiri. Karena proses berpikir dalam hubungan seksual itu teratur, Al-Qur'an mengaturnya agar pemenuhan hasrat seksual tidak bergumul dengan keuntungan orang itu sendiri.

Al-Qur'an memberikan pedoman bagaimana merespon motif hubungan seks dengan cara-cara yang benar dalam bentuk-bentuk sebagai berikut:(Junaedi, 2016)

3.3.2.1.Hubungan Seksual yang Dihalalkan 


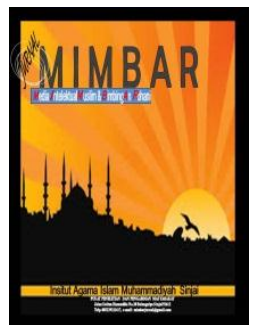

MIMBAR

Jurnal Media Intelektual Muslim dan Bimbingan Rohani

Volume 7, No. 2, 2021

ISSN (print) : 2442-3217 / ISSN (online) : 2716-3806

Email : mimbarjurnal@gmail.com

Homepage : http://journal.iaimsinjai.ac.id/indeks.php/mimbar

DOI $\quad:$ https://doi.org/10.47435/mimbar.v7i2

Syariat Islam menghalakan hubungan seksualme lalui pernikahan yang sah. Pada prinsipnya dalam Islam ada dua tujuan pokok dari lembaga perkawinan. Pertama,mendapat ketentraman hati,terhindar dari kegelisahan dan kebimbangan yang tidak berujung pangkal. Kedua,melahirkan keturunan anak yang salih/salihah.Allah berfirman:

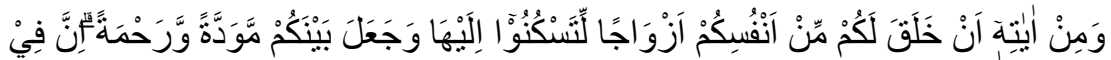

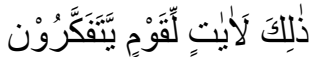

Artinya: dan di antara tanda-tanda kekuasaan-Nya ialah Dia menciptakan untukmu isteri-isteri dari jenismu sendiri, supaya kamu cenderung dan merasa tenteram kepadanya, dan dijadikanNya diantaramu rasa kasih dan sayang. Sesungguhnya pada yang demikian itu benar-benar terdapat tanda-tanda bagi kaum yang berfikir. (QS. ar. Ruum:21).

Dalil di atas menunjukkan, bahwa seksual adalah fitrah manusia yang harus disalurkan melalui nikah. Untuk menciptakan keluarga yang sakinah, mawaddah dan rahmah (Yatimin, 2003). Dan pertama tama kita harus ingat bahwa seks bukanlah sesuatu yang tabu dalam Islam, tetapi dianggap sebagai aktivitas yang sah dalam perkawinan, tidak ada konsep dosa yang dilekatkan padanya.

Seks dianggap sebagai kebutuhan demi prokreasi penciptaan manusia adalah melalui aktifitas seksual (Engineer, 1994). Hadis yang secara jelas membahas tentang jima' adalah hadis yang diriwayatkan oleh Aisyah dan Ibnu Amr bin Ash, dalam Jami’ al-Shaghir hadits tersebut yang artinya:

"Apabila dua bagian yang dikhitan bertemu, maka sungguh telah wajib mandi". Hadits diriwayatkan dari Ibnu Umar dari ,Aisyah. Muhammad Al-Manawiy dalam kitabnya Faidl al-Qadir Syarh Jâmi' al Shaghîr yang men-syarahi kitab hadits tersebut menjelaskan bahwa, maksud darilafadz "bertemu" adalah masuknya hasyafah dan bukan hanya bersentuhan/ menempelnya dua alat kelamin, sedangkan yang dimaksud dengan "alkhitânâni" adalah hasyafah-nya alat kelamin lakilaki dan khifadh atau kelentitnyaalat kelamin perempuan.

Dalam kedua implikasi ini dalam satu kata, khususnya "al-khitânâni" dalam hadits di atas adalah hal biasa di kalangan orang Badui. Menurut dia, kewajiban membasuh ini berlaku untuk (baik yang melakukan hubungan seksual maupun orang yang berhubungan seks) meskipun maninya belum keluar 


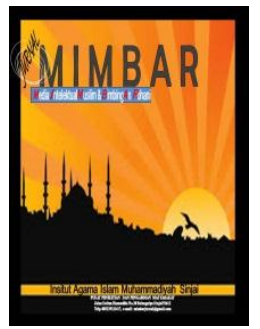

Volume 7, No. 2, 2021

ISSN (print) : 2442-3217 / ISSN (online) : 2716-3806

Email : mimbarjurnal@gmail.com

Homepage : http://journal.iaimsinjai.ac.id/indeks.php/mimbar

DOI

: https://doi.org/10.47435/mimbar.v7i2

sebagaimana dijelaskan dalam hadits di atas. Jadi yang wajib dicuci adalah taghyib alhasyafah.

Penggunaan "al-khitân" dalam hadits bersifat ghalib/umum, oleh karena itu menurut Syafi'i masih wajib digusur jika dhakar yang tidak mau masuk qubul atau dubur, karena disebut juga jima' di farji. Ibnu Hajar berkata: Asbab al-wurûd al-hadits hasan shahih karena setiap pendongeng sampai Aisyah adalah kokoh (tsiqah) dan hadits tersebut takhrij oleh Ibnu Abi Syaibah dan Tabrani. Selain keduanya, hadits ini juga diriwayatkan oleh Imam Syafi'i dalam kitabnya al-Umm dan al-Muhtashor, juga dalam takhrij oleh Imam Ahmad, Imam Nasai dan Imam Tirmidzi dalam kitab-kitab khusus mereka.

\subsubsection{Hubungan Seksual yang Dilarang}

Hubungan seksual yang terlarang dalam buku ini adalah:

a) Hubungan seksual ketika Istri dalam keadaan haid, nifas, dan wiladah, sudah jelas dalam Firman Allah SWT yang berbunyi:

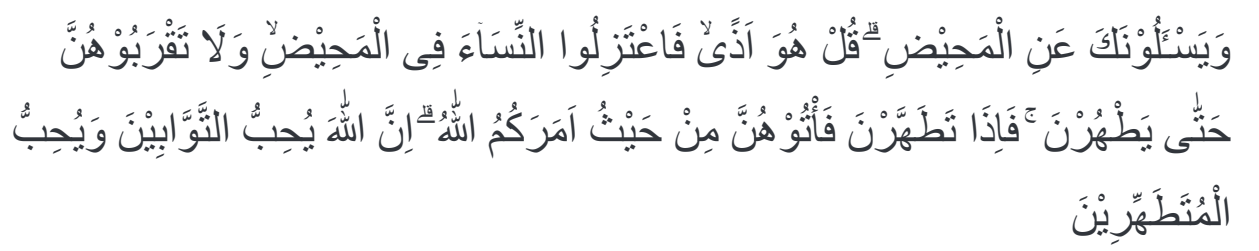

"Dan mereka menanyakan kepadamu (Muhammad) tentang haid. Katakanlah, "Itu adalah sesuatu yang kotor." Karena itu jauhilah istri pada waktu haid; dan jangan kamu dekati mereka sebelum mereka suci. Apabila mereka telah suci, campurilah mereka sesuai dengan (ketentuan) yang diperintahkan Allah kepadamu. Sungguh, Allah menyukai orang yang tobat dan menyukai orang yang menyucikan diri.."(QS. al-Baqarah:222)(Kementerian Agama, 2014)

Tafsir : Pada ayat ini Allah memberikan arahan mengenai standar dalam membangun hubungan suami istri. Juga, mereka, teman-teman, bertanya kepadamu, wahai Nabi Muhammad, tentang siklus bulan ke bulan. Pertanyaan ini diajukan oleh pasangan ketika mereka melihat pria Yahudi melayang menjauh dari pasangannya dan ingin makan dengan mereka ketika mereka pergi, mereka bahkan memposisikan pasangan di rumah yang berbeda. Bagian ini kemudian dibuka untuk memperjelas apa yang harus dilakukan kaki tangan ketika kaki 


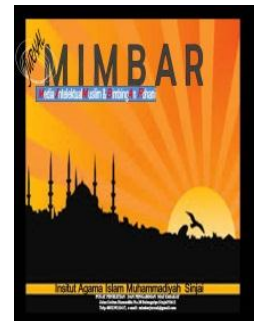

MIMBAR

Jurnal Media Intelektual Muslim dan Bimbingan Rohani

Volume 7, No. 2, 2021

ISSN (print) : 2442-3217 / ISSN (online) : 2716-3806

Email : mimbarjurnal@gmail.com

Homepage : http://journal.iaimsinjai.ac.id/indeks.php/mimbar

DOI

: https://doi.org/10.47435/mimbar.v7i2

tangannya melepaskan. Katakanlah wahai Kurir Allah, bahwa siklus wanita adalah sesuatu, khususnya darah luar biasa yang keluar dari perut seorang wanita, yang berantakan karena baunya yang tidak sedap, tidak sedap dipandang mata, dan menyebabkan siksaan pada wanita. Dengan cara ini menjauhlah dan jangan berbaur dengan pasangan kalian yang lebih baik selama siklus bulanan. Juga, jangan bergerak ke arah mereka untuk berbaur dengan mereka sampai mereka dibersihkan dari darah feminin mereka, selain bersenang-senang selain dari tempat darah keluar. Ketika mereka sempurna dari siklus wanita dan mencuci kemudian, pada saat itu, padukan mereka sesuai dengan apa yang Allah perintahkan kepada kalian dengan asumsi kalian perlu berbaur dengan mereka. Yang pasti, Allah menyukai orang-orang yang meminta maaf atas banyak kesalahan yang mereka buat dan menghargai orang-orang yang membersihkan diri dari kontaminasi luar dengan wudhu' atau mandi (Tafsir, n.d.).

b) Perzinahan

Zina adalah hubungan seks antara seorang pria dan seorang wanita di luar nikah, jadi itu adalah jenis kebejatan seksual. Zina dapat merugikan anak cucu, melenyapkan kemapanan keluarga, memutuskan hubungan keluarga, menyebabkan pelanggaran nafsu, dan merendahkan etika, sebagaimana ditunjukkan oleh cara berpikir Islam tidak ada yang aneh dalam seks jika digunakan untuk reproduksi di dalam tubuh. sistem perkawinan yang sah dan bukan hanya untuk kesenangan. Islam secara tegas melarang perselingkuhan atau seks di luar nikah, karena perselingkuhan atau seks di luar nikah tidak bisa memberikan kemuliaan bagi wanita, perselingkuhan menurunkan seks menjadi kesenangan yang sederhana dan akan membawa lebih banyak pelecehan terhadap wanita, dalam al-Qur'an suami-istri merupakan pakaian satu sama lain.

Dengan demikian, pernikahan bukan hanya dorongan seksual yang menyatukan wanita dan pria, pernikahan memiliki alasan yang lebih tinggi, dan niat yang terhormat, dan merupakan hubungan pemujaan dan penghargaan bersama. Oleh karena itu Allah melarang melakukan zina, Allah berfirman dalam al-Qur'an:

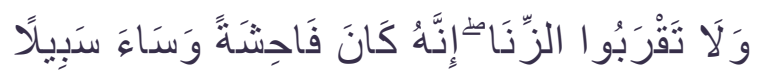




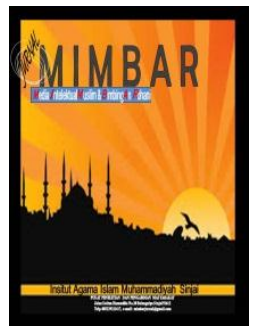

MIMBAR

Jurnal Media Intelektual Muslim dan Bimbingan Rohani

Volume 7, No. 2, 2021

ISSN (print) : 2442-3217 / ISSN (online) : 2716-3806

Email : mimbarjurnal@gmail.com

Homepage : http://journal.iaimsinjai.ac.id/indeks.php/mimbar

DOI $\quad:$ https://doi.org/10.47435/mimbar.v7i2

Artinya; dan janganlah kamu mendekati zina; Sesungguhnya zina itu adalah suatu perbuatan yang keji. dan suatu jalan yang buruk. (QS. alIsraa" :32)(Kementerian Agama, 2014)

Tafsir seperti yang ditunjukkan oleh Syekh Abdurrahman Nasir As Sa'di menjelaskan pentingnya menahan diri. "Selanjutnya, jangan bergerak ke arah perselingkuhan, untuk memastikan itu adalah demonstrasi ofensif dan cara yang paling mengerikan." Di antara apa yang telah difirmankan dan dikehendaki Allah, adalah larangan bergerak ke arah kekafiran bagi pemeluknya (Tafsir, n.d.).

Walau hanya sekedar mendekati belum melakukannya. Karena zina dalam hukum Allah adalah demonstrasi yang mengerikan, perilaku yang sangat mengerikan tidak dapat diakui oleh karakter, akal, dan syariat. Selain itu, cara yang dapat memicu perselingkuhan adalah cara yang paling mengerikan yang dapat berdampak negatif dan berbahaya bagi mereka, tepatnya menghancurkan kehormatan para penganutnya dan yang terakhir adalah kutukan.

\subsubsection{Fungsi seks dalam Al-Qur'an}

3.3.3.1.Pembeda jenis, sebagaimana firman Allah SWT, pada surat an-Najm (53): $45-46$

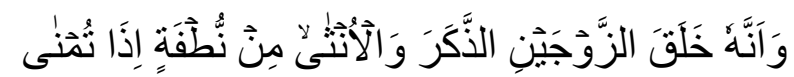

Artinya: 45. Dan bahwasanya Dialah yang menciptakan berpasang-pasangan pria dan wanita. 46. dari air mani, apabila dipancarkan.(Qs. An-Najm/53: 45-46)

Tafsir as-Sa'di/Syekh Abdurrahman tabung Nasir as-Sa'di, seorang ahli terjemahan abad $14 \mathrm{H}$ mengatakan "Dan Dialah yang menciptakan berpasangpasangan," diuraikan oleh Janji-Nya, "Laki-laki dan perempuan." Ini adalah semacam nama yang menggabungkan setiap makhluk hidup, baik orang yang dapat berbicara (manusia) dan makhluk, Dia sendiri yang membuat mereka "dari air mani ketika dipancarkan." Inilah argumentasi terbaik yang menunjukkan kekuatan-Nya, dan hanya Dia yang memiliki kekuatan luar biasa yang telah menjadikan makhluk hidup, baik yang besar maupun yang kecil, dari mani yang rapuh dan yang mengerikan. Kemudian pada saat itu, Allah menciptakan dan 


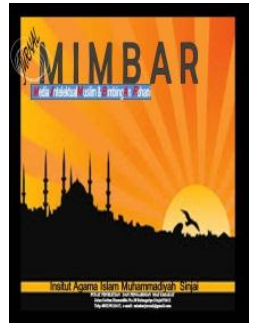

Volume 7, No. 2, 2021

ISSN (print) : 2442-3217 / ISSN (online) : 2716-3806

Email : mimbarjurnal@gmail.com

Homepage : http://journal.iaimsinjai.ac.id/indeks.php/mimbar

DOI

: https://doi.org/10.47435/mimbar.v7i2

menyempurnakan mereka sampai mereka tiba pada kesempurnaan kemudian menjadi manusia yang mendorong tempat yang paling tinggi dalam posisi individu-individu atas ke status paling rendah pada golonga orang-orang yang paling rendah (Web, 2018).

Perbedaan dalam jenis manusia diharapkan untuk membuat kaki tangan, namun juga mengakui hak istimewa dan komitmen dari setiap yang ditetapkan oleh Tuhan kepada manusia (Thalib, 2019).

3.3.3.2.Pengembangbiakan, sebagaimana berfirman Allah dalam surat an-Nisa/4:1

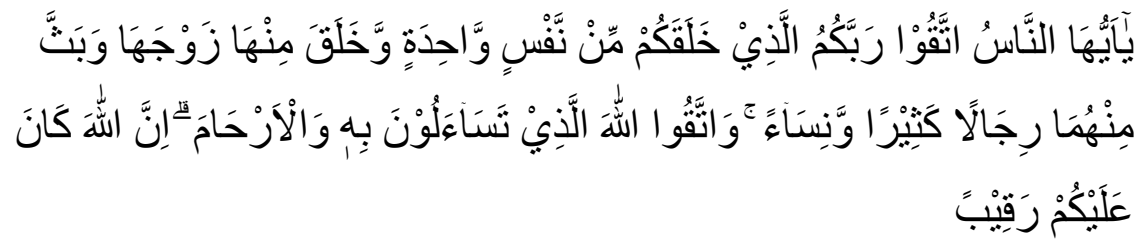

Artinya: "Wahai manusia, bertakwalah kepada Tuhan kalian yang telah menciptakan kalian dari jiwa yang satu; yang telah menciptakan darinya istrinya; dan telah menyebarkan dari keduanya (keturunan) laki-laki dan perempuan yang banyak. Takutlah kalian kepada Allah Zat yang dengan-Nya kalian beradu sumpah dan takutlah kalian memutus silaturrahim. Sungguh Allah adalah Zat yang maha mengawasi kalian.” ( QS. An-Nisa (4): 1)

Tafsir ayat ini, Allah menyatakan bahwa perkembangbiakan manusia terjadi sebagai akibat dari adanya jenis laki-laki dan perempuan. Kapasitas kontras jenis kelamin sebagai metode perkembangbiakan yang merupakan kewajiban mereka merupakan garis pengaturan Tuhan. Kedua jenis unik ini melakukan proliferasi yang merupakan kewajiban mereka di planet ini dengan cara dan cara yang telah ditetapkan Allah. Karena tanpa proliferasi, orang akan mati di planet ini (Thalib, 2019).

Dari penggambaran di atas, tentu saja pemikiran tentang seks tidak hanya terbatas pada jenis kelamin orang, tetapi juga menunjukkan semua yang terjadi karena perbedaan jenis kelamin tersebut. Dan selanjutnya seks dicirikan sebagai dorongan atau keinginan untuk bertindak, yang juga dianggap sebagai nafsu yang dapat memicu baik besar maupun jahat. 


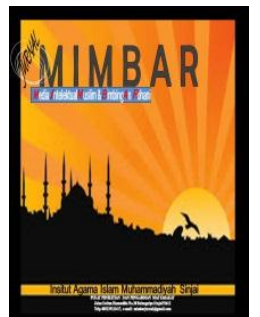

Volume 7, No. 2, 2021

ISSN (print) : 2442-3217 / ISSN (online) : 2716-3806

Email : mimbarjurnal@gmail.com

Homepage : http://journal.iaimsinjai.ac.id/indeks.php/mimbar

DOI

: https://doi.org/10.47435/mimbar.v7i2

Tinjauan Islam tentang seksualitas untuk situasi ini adalah perilaku seksual manusia yang dibenarkan oleh Allah sesuai dengan kecenderungannya, hidup selaras dan memiliki pilihan untuk memenuhi kebutuhan eksistensi ahli yang khas tanpa mengabaikan kebutuhan yang berbeda. Hubungan seksual suami istri dalam perspektif Islam merupakan salah satu unsur keluarga untuk membina keturunan secara halal dan berwawasan sosial dan etis. Kebutuhan alam merupakan kebutuhan esensial yang terdapat pada manusia adalah normal atau sunnatullah jika pasangan saling membutuhkan, dan mengatasi masalah satu sama lain.

\section{Penutup}

Seksualitas adalah tentang bagaimana seorang individu bertemu, hidup dan mengartikulasikan pikirannya sebagai makhluk seksual, semua dalam semua hal yang berkaitan dengan bagaimana seorang individu berpikir, merasa dan bertindak tergantung pada situasinya sebagai makhluk seksual. Semua yang berhubungan dengan seks (ada hubungannya dengan seks) diingat untuk itu. Seks hanyalah satu perspektif, namun secara keseluruhan seksualitas selalu dikaitkan dengan seks (percabulan). Membahas seksualitas dalam Al-Qur'an harus dilakukan dengan hati-hati mengingat masalah ini adalah masalah yang sangat penting. Al-Qur'an memang tidak secara eksplisit menjelaskan tentang seksualitas. Namun juga tidak menghindari diskusi ini. Membahas seksualitas dalam Al-Qur'an lebih condong pada hubungan seksual sebagai pasangan daripada seks sebagai kebebasan dasar individu. Dengan cara ini, percakapan pernikahan sebagai sistematisasi hubungan sosial-seksual memperoleh klarifikasi yang benar-benar lengkap dibandingkan dengan seksualitas sebagai hak semua orang. Isu-isu seksualitas yang tersirat dalam Al-Qur'an mencakup hal-hal, misalnya, pernikahan, perpisahan, perlakuan terhadap pasangan dalam kehidupan rumah tangga (muasyarah bil ma'ruf), iddah dan isu-isu yang diidentifikasi dengan penyimpangan seksual, misalnya, rekening individu. Luth yang melatih homoseksualitas. Hal ini menunjukkan bahwa sebagai kitab yang diberkahi, Al-Qur'an adalah kitab yang bereaksi terhadap persoalan-persoalan kemanusiaan. Pada dasarnya ada dua misi mengapa Alquran membahas seksualitas. Diskusi ini dimaksudkan untuk melawan sejarah seksualitas sebelumnya. Masa lalu yang dimaksud adalah masa sebelum 


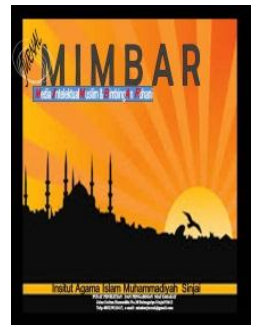

Jurnal Media Intelektual Muslim dan Bimbingan Rohani

Volume 7, No. 2, 2021

ISSN (print) : 2442-3217 / ISSN (online) : 2716-3806

Email : mimbarjurnal@gmail.com

Homepage : http://journal.iaimsinjai.ac.id/indeks.php/mimbar

DOI $\quad:$ https://doi.org/10.47435/mimbar.v7i2

munculnya Islam yang tentunya sering kita sebut sebagai masa jahiliyah. Pada masa pra-Islam ini, tampaknya Al-Qur'an memiliki pandangan yang menghina (memberi makna yang menyinggung). Oleh karena itu, orang yang telah memenuhi syarat didesak untuk segera menikah atau diberi kesempatan untuk melanjutkan hidup dalam ikatan perkawinan.

\section{DAFTAR PUSTAKA}

Akbar, A. (1986). Seksualitas Ditinjau dari Hukum Islam. Ghalia Indonesia.

Al-Asfahāni, A. al-Q. al-H. bin M. bin al-M. al-R. (n.d.). Mu'jam Mufradāt Alfāz al-Qur'ān. Dār al-Kutub al-Ilmiyyah.

Al-Baqiy, M. F. A. (1364). Al-Mu'jam Al-Mufahras Liy Alfadz Al-Qur'an AlKarim. Daar Al-Kutub Al-Mashriyah.

Al-Jawiy, M. N. bin U. (1996). Tausyih Ala Ibn Qasim Qut al-Habib al-Gharib. Dar al-Fikr.

Al-Karim, A.-Q. (2008). Al-Qur'an dan terjemahannya. Departemen Agama RI. Bandung: Diponegoro.

Al-Manawiy, M. A. al-R. (1972). Faidl al-Qadir Syarh Jami" al-Saghir (Juz 1). Dâr alFikr.

Asrari, A. M. (1998). Berkhitan Akikah Kurban Yang Benar Menurut Ajaran Islam. Al Miftah.

Engineer, A. A. (1994). Hak-Hak Perempuan Dalam Islam. Yayasan Bentang Budaya.

Hannah, N. (2017). Seksualitas dalam Alquran, Hadis dan Fikih: Mengimbangi Wacana Patriarki. Wawasan: Jurnal Ilmiah Agama Dan Sosial Budaya, 2(1), 45-60.

Hazairin. (1961). Hukum Kekeluargaan Nasional Indonesia. Tintamas.

Junaedi, D. (2016). Penyimpangan Seksual yang Dilarang Al Quran. Elex Media Komputindo.

Kbbi, K. B. B. I. (2016). Kamus Besar Bahasa Indonesia (KBBI). Kementerian Pendidikan Dan Budaya.

Kementerian Agama, R. I. (2014). Al-Quran dan Terjemahnya. Jakarta: PT. Hati Emas.

Kusnadi, M. I. S. (2020). ISU LGBT (LESBIAN, GAY, BISEKSUAL \& TRASGENDER) DALAM AL-QUR'AN. MEDIA INTELEKTUAL MUSLIM DAN BIMBINGAN ROHANI, 6(2).

Marzuki, U. S. (2001). Perilaku Seks Menyimpang Dan Seksualitas Kontemporer Umat Islam. UII Press, Yogyakarta.

Masters, W. H., Johnson, V. E., \& KOLODN, Y. (1992). Human Sexuality. 
Volume 7, No. 2, 2021

ISSN (print) : 2442-3217 / ISSN (online) : 2716-3806

Email : mimbarjurnal@gmail.com

Homepage : http://journal.iaimsinjai.ac.id/indeks.php/mimbar

DOI : https://doi.org/10.47435/mimbar.v7i2

Harper Collins Publisher.

Muhdlor, A. A. A. Z., \& Ali, A. (1996). Kamus Kontemporer Arab-Indonesia. Yayasan Ali Maksum Pondok Pesantren Krapyak.

Tafsir. (n.d.). Tafsir learn quran. Tafsir.Learn-Quran.Co. Retrieved October 20, 2021, from https://tafsir.learn-quran.co/id/surat-3-al-imran/ayat-14

Thalib, M. (2019). 30 tuntunan seksualitas Islami.

Tholabah, M. al-. (2002). Tharaz al-Mutaqoddimin fi Adillati Matni Qurrati alAin. Demu.

Web, T. (2018). Surat An-Najm Ayat 45-46. Tafsirweb.Com. https://tafsirweb.com/10160-surat-an-najm-ayat-46.html

Yatimin. (2003). Etika seksual dan penyimpangannya dalam Islam. Azmah. 